\title{
Do Learning and Development Interventions Motivate Employees at PT Danone Indonesia? Applying McClelland's Theory of Motivation to FMCG Industries
}

\author{
Author : \\ Maria Jacinta Arquisola ${ }^{1}$ and Sabiqa Uqda Walid Ahlisa ${ }^{2}$ \\ Email : mjarquisola@president.ac.id \\ Department of Management, School of Business President University, Indonesia
}

\begin{abstract}
This research aimed to determine whether there is a relationship between employee motivation and learning and development programs at one of Indonesia's biggest FMCG companies, PT Danone Indonesia. Guided by McClelland's Theory of Motivation, three independent variables were analyzed relative to learning and development: the need for achievement, the need for power, and the need for affiliation. The research used quantitative method through a survey to gather data from 105 participants working at PT Danone Indonesia who, at the time of the study, had recently joined a series of learning and development programs. Data was analyzed using multiple regressions analysis. Findings show that employees are motivated to undergo learning and development because they want to fulfill two motivational needs: the need for power, and the need for achievement, the former being the highest motivator. On the other hand, the need for affiliation was not a strong motivator to encourage them to learn and develop. Results also show that the interest for learning and development could be explained by $42 \%$ of the variables. Implications for research and practice are discussed.
\end{abstract}

\begin{abstract}
ABSTRAK
Penelitian ini bertujuan untuk mengetahui apakah ada hubungan antara motivasi karyawan dan program pembelajaran dan pengembangan di salah satu perusahaan FMCG terbesar di Indonesia, PT Danone Indonesia. Dipandu oleh Teori Motivasi McClelland, tiga variabel independen dianalisis relatif terhadap pembelajaran dan pengembangan: kebutuhan akan prestasi (need for achievement), kebutuhan akan kekuasaan (need for power), dan kebutuhan akan afiliasi (need for affiliation). Penelitian ini menggunakan metode kuantitatif melalui survei untuk mengumpulkan data dari 105 peserta yang bekerja di PT Danone Indonesia yang, pada saat penelitian, baru bergabung dengan serangkaian program pembelajaran dan pengembangan. Data dianalisis menggunakan analisis regresi berganda. Temuan menunjukkan bahwa karyawan termotivasi untuk menjalani pembelajaran dan pengembangan karena mereka ingin memenuhi dua kebutuhan motivasi: kebutuhan akan kekuatan, dan kebutuhan untuk berprestasi, yang pertama menjadi motivator tertinggi. Di sisi lain, kebutuhan untuk berafiliasi bukanlah motivator yang kuat untuk mendorong mereka untuk belajar dan berkembang. Hasil juga menunjukkan bahwa minat untuk belajar dan pengembangan dapat dijelaskan oleh $42 \%$ dari variabel. Implikasi untuk penelitian dan praktik dibahas.
\end{abstract}

Keywords: Learning, development, motivation, McClelland's Theory, FMCG, Indonesia 160 | H a I a m a 


\section{A. INTRODUCTION}

According to Suma and Lesha (2013), when organizations focus on improving human resources quality, such intervention will result in a big impact to organizational success, and employees have a key role to play in this enterprise (Bhatti, Aslam, Hassan, \& Sulaiman, 2016). Companies need competent human capital resources to support them in achieving their goals. In creating superior competitive advantage for firms, companies must provide the employee additional knowledge and skills in facing global challenges, like globalization, new and rapid technology, development of e-commerce, faster and efficient systems related to mechanization and automation. Singh (2015) argues that competent human resources are currently in high demand and organizations realize the importance of people resources in this current competitive and technological age.

Importantly, in order to face rapid-changing environments and competitive innovation, learning in organizations is considered to be very important (Kyndt, Vermeire, and Cabus, 2016). This means that a company's learning division has a big role in giving employees the chance to improve their knowledge, skills, and ability (KSA or competencies) to be more productive. Therefore, to increase Indonesia's human development index, which is low compared to other countries (see Figure 1 below), one important intervention is to give learning and development opportunities to every employee, regardless of their position in the company. One such company is PT Danone Indonesia who operates in the fast -moving consumer goods sector.

This study focused on the learning and development programs that PT Danone Indonesia is offering to its employees as part of its desire to foster learning and growth. PT Danone is an international company holding top position in the manufacture of healthy food, e.g. fresh dairy products, early life nutrition, water, and medical nutrition. Its mission is to bring health through food to as many people as possible. Danone has over 190 production plants and more than 100,000 employees (Danone, 2017). 
Fig. 1 - Human Capital Development Index, 2015

\begin{tabular}{|c|c|c|c|c|c|c|c|c|}
\hline \multirow{2}{*}{$\begin{array}{l}\text { Negara } \\
\text { Country }\end{array}$} & \multicolumn{4}{|c|}{$\begin{array}{l}\text { Nilai } \\
\text { Score }\end{array}$} & \multicolumn{4}{|c|}{$\begin{array}{c}\text { Peringkat } \\
\text { Rank }\end{array}$} \\
\hline & 2012 & 2013 & 2014 & 2015 & 2012 & 2013 & 2014 & 2015 \\
\hline (1) & (2) & (3) & (4) & (5) & (6) & (7) & (8) & (9) \\
\hline Amerika Serikat/USA & 0,915 & 0,916 & 0,918 & 0,920 & 8 & 8 & 11 & 11 \\
\hline Arab Saudi/Saudi Arabia & 0,830 & 0,841 & 0,845 & 0,847 & 39 & 38 & 38 & 39 \\
\hline Australia & 0,933 & 0,936 & 0,937 & 0,939 & 3 & 3 & 3 & 3 \\
\hline Bangladesh & 0,565 & 0,570 & 0,575 & 0,579 & 140 & 142 & 141 & 141 \\
\hline Belanda/Netherlands & 0,922 & 0,923 & 0,923 & 0,924 & 5 & 5 & 7 & 7 \\
\hline Belgia/Belgium & 0,889 & 0,890 & 0,895 & 0,896 & 21 & 24 & 21 & 22 \\
\hline Brazil & 0,734 & 0,747 & 0,754 & 0,754 & 88 & 80 & 79 & 79 \\
\hline Denmark & 0,924 & 0,926 & 0,923 & 0,925 & 4 & 4 & 6 & 6 \\
\hline Federasi Rusia/Russian Federation & 0,799 & 0,803 & 0,805 & 0,804 & 48 & 48 & 48 & 49 \\
\hline Filipina/Philippines & 0,671 & 0,676 & 0,679 & 0,682 & 116 & 116 & 114 & 116 \\
\hline Finlandia/finland & 0,887 & 0,890 & 0,893 & 0,895 & 24 & 23 & 23 & 23 \\
\hline Hongkong/Hongkong SAR & 0,907 & 0,913 & 0,916 & 0,917 & 13 & 10 & 12 & 12 \\
\hline India & 0,599 & 0,607 & 0,615 & 0,624 & 133 & 132 & 131 & 131 \\
\hline Indonesia & 0,677 & 0,682 & 0,686 & 0,689 & 114 & 113 & 113 & 113 \\
\hline Inggris/United Kingdom & 0,899 & 0,904 & 0,908 & 0,909 & 16 & 16 & 16 & 16 \\
\hline Italia/Italy & 0,876 & 0,877 & 0,881 & 0,887 & 26 & 27 & 27 & 26 \\
\hline Jepang/Japan & 0,894 & 0,899 & 0,902 & 0,903 & 17 & 17 & 17 & 17 \\
\hline Jerman/Germany & 0,919 & 0,920 & 0,924 & 0,926 & 7 & 7 & 4 & 4 \\
\hline Kamboja/Cambodia & 0,546 & 0,553 & 0,558 & 0,563 & 144 & 144 & 143 & 143 \\
\hline Kanada/Canada & 0,909 & 0,912 & 0,919 & 0,920 & 9 & 12 & 10 & 10 \\
\hline Kazakhstan & 0,782 & 0,789 & 0,793 & 0,794 & 57 & 56 & 56 & 56 \\
\hline Korea Selatan/Korea, Rep. of & 0,891 & 0,896 & 0,899 & 0,901 & 19 & 18 & 18 & 18 \\
\hline Kuwait & 0,796 & 0,787 & 0,799 & 0,800 & 52 & 57 & so & 51 \\
\hline Malaysia & 0,779 & 0,783 & 0,787 & 0,789 & 61 & 59 & 59 & 59 \\
\hline
\end{tabular}

Source: BPS-Statistics Indonesia, 2017

The justification for this study rests on several research gaps identified. First, there is limited research on the application of McClelland's theory on employee motivation and learning in fast moving consumer goods (FMCG), especially in Indonesia. Second, the researchers found that in Indonesia research on human capital development especially in the FMCG sector is low. This is telling as Indonesia's HCI competitiveness index is low compared to other countries hence greater attention must be given to learning and development in the industry sectors. Lastly, most of topics only observed about employee motivation in general, and not specific into McClelland's theory with learning and development as variables.

\section{Research Setting: PT Danone Indonesia}

Danone settled in Indonesia in 1998. Danone in Indonesia is represented by three categories of business such as Waters, Early Life Nutrition, and Advanced Medical Nutrition. It signed a strategic alliance with Aqua, an Indonesian brand of bottled water launched in 1973. With this partnership, the brand strengthened its market position becoming the largest producer of bottled mineral water in Indonesia. In 2005, Mizone was launched in Indonesia. With brands such as Aqua, VIT, Mizone, Bebelac, Nutrilon, and SGM, currently PT Danone Indonesia has more than 15,000 employees, spreading across the province through more than 1.5 million outlets and 23 
factories.

In Figure 2 below, the data shows that every month Danone Academy Indonesia conducts learning evaluation. This evaluation shows that the evaluation score is unstable. The evaluation could be influenced by employees' motivation to join learning and development, or the quality of learning and development in Danone Indonesia employees see as not fulfilling their needs.

Figure 2. Learning Evaluation at PT Danone Indonesia, January - December 2018

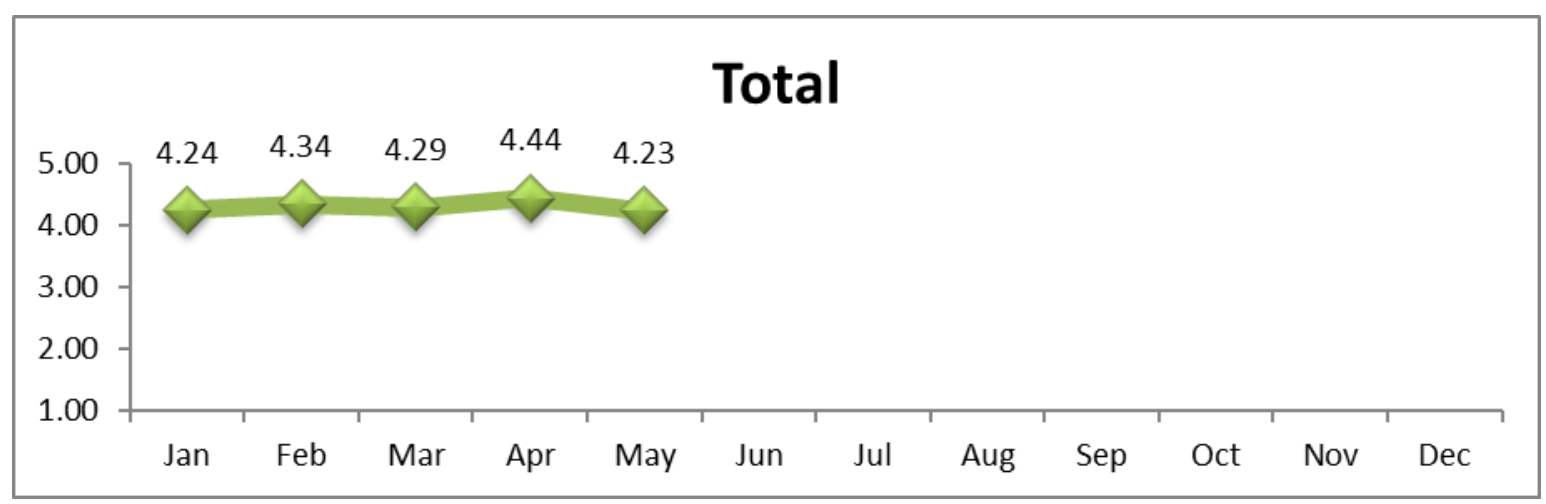

This could be a problem because the company already invests big on their training programs but sometimes the employees do not show any improvement or even not joining the program. For example, when the learning division invites participants to training, some participants do not attend on the day of training and impacts the evaluation score. This can be costly. It could affect the employees' competencies that are not improved at all.

\section{B. LITERATURE REVIEW}

\section{Learning and Development}

This study begins with discussing the important guiding frameworks used in examining how motivation influences employees' learning and development processes at PT Danone Indonesia. The first of these frameworks is learning and development. Based on Kaya and Patton (2011 cited in Dev and Jyoti, 2015) definition, learning is defined as the process of acquisition of information and shared knowledge which increase the effectiveness of either individual or organizational elements. According to Goldstein and Ford (2002), learning and development refers to the building of expertise as a function of systematic training efforts. This systematic 163 | H a I a m a 


\section{Vol. 4 No. 2 Firm Journal of Management Studies}

training effort refers to the idea that training is intentional. The result of learning includes improvement of an employee's competencies (knowledge, skills, and attitudes) critical for successful job performance. Improvement is measured by the extent to which the learning that results from training leads to meaningful changes in the work environment. Therefore, training is seen as integral to facilitating larger scale organizational change and development issues. Training not only increases the competitive advantage of a company but the most important is improving human capital (Cheung and Chan, 2012).

Training is one of the learning methods that are planned. There are other methods besides training to educate employees. Training is a facility from company for employee to learn about their job or competencies (Noe, 2010). Training gives benefit in the form of gaining competitive advantage. Training is not only involved in developing basic skill to gain competitive advantage, but company must view training widely as a direction to create intellectual capital (Noe, 2010). Intellectual capital means expertise in basic skills, advanced skills, understand about customer or manufacturing system, and creativity from self-motivated. According to Brinkerhoff and Apking (2001), high-leverage training has objective in order to ensure training is effectively done, they correlate goals and strategic business with instructional design process and benchmarks training program of the company with other companies training programs. According to Noe (2010) the economic cycle and globalization are some of the common factors prodding companies to jeep learning. Based on Cheung and Chan (2012), people also keep learning because their motives are economic growth salary, and job promotion, while Arguinis and Kraiger (2009) believe that people liked to be trained because they need updating in their skills and abilities to maintain a competitive advantage because global contexts are changing. Globalization and technological advances currently require organizations to create speedy adjustment in knowledge, skills, and abilities to remain relevant and succeed.

According to Yeung (2017), developing learners with critical thinking skills, problem solving skills and communication skills is necessary. Employee development is fundamental in attaining company's mission, objective, and values that are related with business results. These important results are employee retention and a competent or talented management team. Usually, development is focused on management levels while those who need to improve specific skills for daily work are line employees. Therefore, development becomes necessary for company 
since there is increasing the need in employee engagement and how to develop talent management (Noe, 2010). Individual who have a high level of competitiveness are active in events or activities in which they can prove themselves to others (Cheung and Chan, 2012).

\section{Theory of Motivation}

Motivation to learn is a willingness of the employee to obtain knowledge from training programs offered by companies (Noe, Hollenbeck, Gerhart, and Wright, 2015). The motivation to learn also refers to the willingness and the desire employees to participate in training and development to get learning experience (Kyndt, Vermeire, and Cabus, 2016). The early proponents of motivation were Abraham Maslow (Bhatti, Aslam, Hasan, and Soelaiman 2016, p.35) who defined motivation in terms of five important needs which are a) Physiological, b) Safety/Security, c) Social/Love, d) Self Esteem, and e) Self-actualization. Frederick Herzberg (1964 cited in Bhatti et al. 2016, p.35), argued about motivation could be explained in terms of two factors: motivational factors and hygiene factors which are the indicators of satisfaction and dissatisfaction. Motivational factors can include achievement, career advancement, personal growth, job interest, recognition, and responsibility. Meanwhile, hygiene factors are company policies, quality of supervision, relations with others, personal life, a rate of pay, job security, and working conditions. Even in the current world of work, the theory of motivation has found utilization in newer ways of studying how firms operate, e.g. in green supply chain management, research has found that the motivation to apply green principles in supply chain operations is deeply influences by an organization's top-level support for such an enterprise (Vanpoucke, Lieven, \& Engelshoven, (2016).

\section{McClelland's Theory of Motivation}

McClelland's theory argues that people are motivated if these three needs are met: a) need for affiliation, b) need for power, and c) need for achievement (Royle and Hall, 2012). These three needs are discussed. This theory is known as learned needs that impact on personality and organizational development.

McClelland's learned needs theory is one of the motivation theories that has aimed closely with learning concepts (Ivancevich and Matteson, 2002). McClelland states that if the individual has a strong need to learn, the effect will be to motivate him/her to perform desired behaviours that 165 | H a I a ma 
lead to individual and professional satisfaction.

\section{Need for Achievement}

The need for achievement represents an individual's satisfaction in jobs that involve both high skill levels and difficult challenges (Royle and Hall, 2012). Need for achievement is the desire of people to have high intensity in success and fear of failure. Self- efficacy is the belief of individuals that they can successfully bring the actions necessary to achieve intentions. High selfefficacy enables employees to have higher motivation and more involvement in the learning process (Al-Eisa, Furayyan, and Alhemoud, 2009; Kyndt, Vermeire, and Cabus, 2016). This motivation is able to increase an employees' sense of self-efficacy and an opportunity to invest themselves in their activities (Baldwin, Garza Reyes, Kumar, and Lona, 2014).

According to Al-Eisa, Furayyan, and Alhemoud (2009), employees who have high confidence in their capabilities are more likely to be better prepared and have positive expectations about training, are more motivated to seek opportunities for training and learning the material of the training programs that they attend. According to Ivancevich and Matteson (2002), there are several factors that define a high need for achievement. The first result, people tend to like taking responsibility in solving the problem. Second, individual will set moderate achievement goals and inclined to take calculated risks. Lastly, the individual has the highest attention to get feedback for their performance. Therefore, the study's first hypothesis is:

H1: There is a relationship between need for achievement and employees' motivation for learning and development at PT Danone Indonesia.

\section{Need for Affiliation}

The need for affiliation is the motivation to find connections and need support from their environment. They prefer to be liked by others and accepted by other people who know them. The individual with high need for affiliation has a low need for power (Ondabu, 2014, p. 17). On the other hand, need for affiliation is more concerned with social connection. Individuals who have this need will try to get relationship satisfaction. Supervisor support is important for need for affiliation to be satisfied (Al-Eisa, Furayyan, and Alhemoud, 2009). It is the extent of supervisors enforcing participation in training, innovation, acquired knowledge, and provide 
recognition to employees involved in learning and development. Several researchers found the role of leader such as transformational leader as a mediator between creativity, self-efficacy, and learning orientation of employees is consistent with this need for support (Dev and Jyoti, 2015). Transformational leaders directing subordinates by sharing information, enhancing employee's visions, knowledge, competencies and commitments to learning affect employee creativity directly. Therefore, the study's second hypothesis is:

$\mathrm{H} 2$ : There is a relationship between need for affiliation and employees' motivation for learning and development at PT Danone Indonesia.

\section{Need for Power}

Immonen, Koskinen, and Porkka, (2011) suggest that an employees' motivation to learn is vested on self-interest and finding power and wealth. The need for power is the desire to control and influence others (Ondabu, 2014).

Usually, people who have this motivation need higher reputation and self-esteem. Hence, they strive to become successful managers and more efficient in daily work. According to Cheung and Chan (2012), the need for power (job promotion), salary, and economic growth has correlation with competitiveness motive. Based on Porter, Riesenmy, and Fields (2016) the motivation to lead refers to motivation influencing employee's decisions to take leadership roles as well as predict the level of effort and persistence applied in developing leadership capabilities. Furthermore, leadership development and formation in the organization is usually a process involving interplay of characteristics between people, and aspects of the work environment (Porter, Riesenmy, and Fields, 2016). In other words, the need for power is part of intrinsic motivation that is a powerful driver to challenge employees desiring leadership roles, and potential for improvement and development of professional knowledge and abilities (Cruz, Perez, and Cantero, 2009). Therefore, the study's third hypothesis is:

H3: There is a relationship between need for power and employees' motivation for learning and development at PT Danone Indonesia. 


\section{METHODOLOGY}

\section{Sampling, data collection and analysis}

The researcher used quantitative method for this study, using a five-Likert survey questionnaire to collect data from a random selection of 105 employees of PT Danone Indonesia who were undergoing a training and development intervention. From this number, 52\% of respondents were female and 48\% were males. Respondents were between 21 years of age and above 50 years of age. Majority of the employees have average employment of $3-5$ years.

In this research, validity test was conducted on the survey questionnaire with 15 pilot respondents. Instrument was valid as the result of corrected item-total correlation is greater than 0.514. All results showed validity for 19 questions and 3 questions for respondents' profile. Data was analyzed using descriptive statistics and multiple regression analysis. Descriptive statistics was used to describe numerical data of the questionnaire using frequency distribution and measures of central tendency. In this study frequency distribution shows the dispersion of cases into the categories, such as gender, age of respondents, education, length of employment, etc. (Neuman, 2014). Multiple regression analysis was used to determine the extent of influence of the three independent variables (need for achievement, need for affiliation, and need for power) with the dependent variable (learning and development).

\section{RESULTS}

\section{Multiple Regression Analysis}

The regression coefficient or B1 value is 0.301 which means that when Need for Achievement (NAch) is high, it will be followed by an increase of $30.1 \%$ attention in learning and development. Data also shows that Need for Affiliation (Naff) and Learning and development is negative, where the regression coefficient or B2 value $(-0.205)$ which means there is the need for affiliation does not influence the motivation of employees for learning and development. It could be due to the fact that the motivation to learn actually is not about making connections and friendship. Furthermore, it can be seen that the relationship between Need for Power and Learning and development in Danone Indonesia is positive, as shown by the coefficient or B3 value in the regression equation (0.529). This means that when the Need for Power of employees 
is high, then it will be followed by increased attention of $52.9 \%$ in learning and development.

Table 1. Multiple Regressions

Result of Coefficients

\begin{tabular}{|c|c|c|c|c|c|c|c|c|}
\hline & & \multicolumn{2}{|c|}{$\begin{array}{c}\text { Unstandardized } \\
\text { Coefficients }\end{array}$} & \multirow{2}{*}{$\begin{array}{c}\begin{array}{c}\text { Standardized } \\
\text { Coefficients }\end{array} \\
\text { Beta } \\
\end{array}$} & \multirow[b]{2}{*}{$\mathrm{t}$} & \multirow[b]{2}{*}{ Sig. } & \multicolumn{2}{|c|}{$\begin{array}{c}\text { Collinearity } \\
\text { Statistics }\end{array}$} \\
\hline \multicolumn{2}{|c|}{ Model } & $\mathrm{B}$ & Std. Error & & & & Tolerance & VIF \\
\hline 1 & (Constant) & 1.681 & .352 & & 4.770 & .000 & & \\
\hline & Average_NAch & .301 & .145 & .281 & 2.077 & .040 & .305 & 3.282 \\
\hline & Average_NAff & -.205 & .113 & -.245 & -1.816 & .072 & .306 & 3.269 \\
\hline & Average_NPow & .529 & .131 & .605 & 4.052 & .000 & .250 & 3.995 \\
\hline
\end{tabular}

a. Dependent Variable: Average LD

\section{Coefficient of Determination $\left(R^{2}\right.$ Test)}

As shown in Table 2 below, the value of $\mathrm{R}$ square is 0.419 or $41.9 \%$, which means independent variables (Need for Achievement, Need for Affiliation, and Need for Power) have relationship and influence to dependent variable (learning and development program) by $41.9 \%$. Meanwhile, for the rest $58.1 \%$ of Learning and development Program is influencing and has relationship with other variables.

Table 2. Model Summary

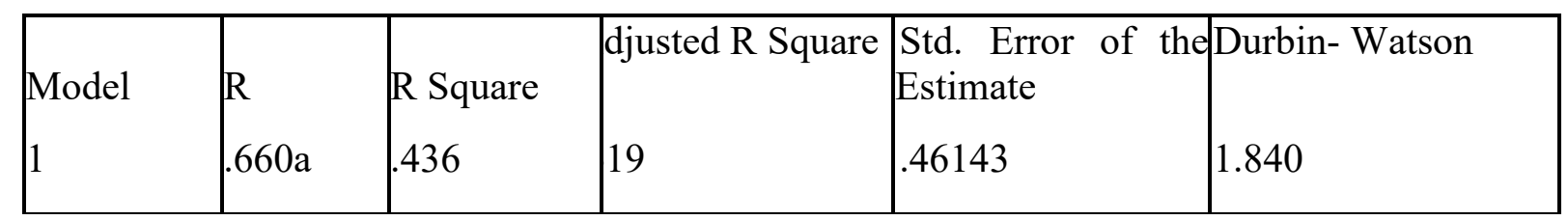

Predictors: (Constant), Average_NP, Average_NAff, Average_NAch

Dependent Variable: Average LD 


\section{Hypothesis Testing T- Test}

The result in Table 3 shows that the $t$ value for this NAch variable is 2.077 and the significance value is 0.040 . This value is lower than the significant level that the researcher used is $0.05(5 \%)$. It means that $\mathrm{H} 1$ is accepted. The $\mathrm{t}$ value for NAff is 1.816 and the significance value is 0.072 . This value is higher than the significant level that the researcher used is $0.05(5 \%)$. It means that $\mathrm{H} 2$ is rejected. The $\mathrm{t}$ value for NPow shows $\mathrm{t}$ value for this variable is 4.052 and the significance value is 0.000 . This value is lower than the significant level that the researcher used is $0.05(5 \%)$. It means that $\mathrm{H} 3$ is accepted.

Table 3 - Table of Coefficientsa

\begin{tabular}{|c|c|c|c|c|c|c|c|c|}
\hline & & \multicolumn{2}{|c|}{$\begin{array}{c}\text { Unstandardized } \\
\text { Coefficients }\end{array}$} & \multirow{2}{*}{$\begin{array}{c}\begin{array}{c}\text { Standardized } \\
\text { Coefficients }\end{array} \\
\text { Beta } \\
\end{array}$} & \multirow[b]{2}{*}{$\mathrm{t}$} & \multirow[b]{2}{*}{ Sig. } & \multicolumn{2}{|c|}{$\begin{array}{l}\text { Collinearity } \\
\text { Statistics }\end{array}$} \\
\hline \multicolumn{2}{|c|}{ Model } & $\mathrm{B}$ & Std. Error & & & & Tolerance & VIF \\
\hline 1 & (Constant) & 1.681 & .352 & & 4.770 & .000 & & \\
\hline & Average NAch & .301 & .145 & .281 & 2.077 & .040 & .305 & 3.282 \\
\hline & Average NAff & -.205 & .113 & -.245 & -1.816 & .072 & .306 & 3.269 \\
\hline & Average NPow & .529 & .131 & .605 & 4.052 & .000 & .250 & 3.995 \\
\hline
\end{tabular}

a. Dependent Variable: Average LD

\section{E. DISCUSSION}

The need for power influences employee motivation to join learning and development programs

Data shows that the need for power showed the significant value is 0.000 , which means it is lower than the significant level of 0.05 . The regression results $\mathrm{B}$ coefficient is 0.529 . This means that need for power has relationship with learning and development and it has the highest significant value from other independent variables. This variable confirms research by Benowitz (2001) which argued that need for power refers to the company's strict rules and obey the processes to obtain promotion to a higher level. It means Danone Employees have high motivation to learn in order to fulfill the need of power. They join learning programs to learn 
how to attain authority and control other people. Learning and development thus become an opportunity to have higher competencies for higher level responsibilities. According to Noe (2010), individuals who received training designed to develop skill specifically are the people who have high concern for development. It means Danone employees are motivated to learn due to their need for power through higher level of jobs or responsibilities. Immonen, Koskinen, and Porkka (2011) found that the motivation to learn is due to self-interest and finding power and wealth. Employee development provide those employees with leadership potential to prepare themselves for future higher positions. Based on Porter, Riesenmy, and Fields (2016), the need for power is a big motivator, which is the reason why many people take leadership roles and develop leadership capabilities through learning and development. Actually, leadership potential is needed, which is developing learners with critical thinking skills, problem solving skills and a communication skill are necessary. However, for people who are competition oriented, they are often ambitious and will strive for advancement in specific cultures (Cheung and Chan, 2012). This advancement increases the competencies and leads employees to have high- competitive advantage through training.

\section{The need for achievement influences employee motivation to join learning and development programs}

Results show that the need for achievement influences PT Danone employees' desire to join learning and development programs. This variable has significant value less than $0.05(0.040)$, and regression B1 value of 0.301 , which means there is correlation with learning and development. The need for achievement is therefore one of the motivation factors that influence their motivation to learn. Employees recognize that attention for their development will greatly shape their performance in the future. It is supported by previous research (e.g. Royle and Hall, 2012) which argued that the need for achievement is consistent with people's desire to be successful and avoid or fear failure. According to Ivancevich and Matteson (2002), if an individual has strong need to achieve, it will motivate the individual to use desirable behavior leading to a satisfactory conclusion. This means that it will encourage the employees to strive to obtain more learning opportunities if such facilities are given to increase employee job satisfaction, or enhance their competencies to achieve the organizational objectives. This result confirms research (e.g Al-Eisa, Furayyan, and Alhemoud, 2009) which argued that self- efficacy 
is the belief of individuals that they can successfully bring the actions necessary to achieve their personal intentions. Learning and development has various useful application for employees, and among them, the most effective is training program. Thus, this statement proves that by having high self-efficacy, employees may be able to have higher motivation and more involvement in the learning process (Kyndt, Vermeire, and Cabus, 2016).

This motivation also gives the employee the opportunity to invest in meaningful and productive activities (Baldwin, Garza Reyes, Kumar, and Lona, 2014). When Danone employees have high need for achievement, they will use this chance as their way to enhance their Knowledge, Skills, or Attitudes (KSAs) for higher productivity. It is important to maintain the company's productivity in the market and survive stiff competition. If the employee has improved competencies, the company's productivity and creativity will also increase since they have new skills and knowledge gained from training. Usually, training provides specific lessons or topics that employees can choose based on their needs. Thus, employees will be able to choose which training can support them highly at work.

\section{The need for affiliation does not influence employee motivation to join learning and development program}

Data shows that the need for affiliation has a significant value 0.072 that is greater than significant level of 0.05 . The regression B coefficient is $(-0.205)$ which shows a negative result. It means that need for affiliation has no relationship with learning and development. This result is supported by Ondabu (2014) who argued that individuals with high need for power will have low need for affiliation. The need for affiliation refers to maintaining good social relationships and how to be accepted by other group members. This argument means that employees of Danone Indonesia have no interest to join learning and development program because they really want to meet new friends or they would like to establish new relationships.

In Danone Indonesia, it was hard to find an employee who had taken training just because they want to establish more connection, and relationships with other employees from another division or department. On the other hand, the result shows that there are no employees in Danone Indonesia interested to join learning and development because they are being directed by their leaders, and employees feel that it is like a directive or compulsory activity. Directive leaders 
would not work in requiring employees to learn; on the other hand, if a leader is a transformational leader, employees will be encouraged to have higher learning orientation (Dev and Jyoti, 2015). Transformational leaders directing subordinates by sharing information, enhancing employee's visions, knowledge, competencies and commitments to learning, affect employee creativity directly. In this study, most of the respondents tend to be highly-motivated to learn because they want to acquire more power in the work place. It could also be due to the young age of the employees, coupled by their short term of employment in the company. They need training for a brighter future. Therefore, this research has proven that employee motivation is not only influencing employee performance, but also influencing why the employee want to keep learning.

\section{IMPLICATIONS FOR RESEARCH AND PRACTICE}

The study found that a strong motivator for learning and development is the need to have higher authority and responsibility. This implies that PT Danone Indonesia must pay attention to the career development of the employees who have finished set courses of learning and development, e.g. those who have completed may be scheduled for a promotion, or salary increase, or given recognition. Employees will be disappointed if a career development program is not in place. Similarly, the need for achievement was felt strongly by employees. Many of them would like PT Danone Indonesia to recognize their achievement in whatever form that are within company policies. Such recognition could be in the form of, for example, sponsored or subsidized higher education grant, attending conferences, etc. or they are given special assignments that can stimulate engagement with other staff in other fields. They will be encouraged more to learn. On the other hand, the need for affiliation may be encouraged in the course of learning through team-building exercises or team projects that will enable employees to work together on projects that will make them feel they are part of a bigger team that works for company goals.

Future research must look into the effects of motivation theories on millennials need to learn, and the types of development interventions that are suitable for this generational cohort. 


\section{F. CONCLUSION}

In this study, it has been found that employees are motivated to learn if they believe learning and development interventions will produce for them greater results such as fulfilling their need for power and achievement. The reverse is true for need for affiliation. Employees at PT Danone Indonesia do not see it as a motivator to learn. This is because employees of Danone Indonesia join learning and development programs not only to find relations or connection with others; employees need it more for achievement and most of all, power. These two needs must be met in order for employees to stay engaged with PT Danone. On the other hand, the company must undertake further research to find out how their learning and development interventions could be designed in such a way that employees will find it as a good mechanism to improve their affiliation and network.

\section{REFERENCES}

Al-Eisa, A., Furayyan, M. A., \& Alhemoud, A. M. (2009). An Empirical Examination of The Effects of Self Efficacy, Supervisor Support and Motivation to Learn on Transfer Intention. Management Decision, 47(8), 1222-1225.

Arguinis, H., \& Kraiger, K. (2009). Benefits of Training and Development for Individuals and Teams, Organizations, and Society. Annual Review of Psychology, 60, 451 474.

Baldwin, C., Garza Reyes, J. A., Kumar, V., \& Lona, L. R. (2014). Personal Development Review (PDR) Process and Engineering Staff Motivation: A Case Study Investigation in Manufacturing Firm. Journal of Manufacturing Technology Management, 25(6), 827847.

Benowitz, E. A. (2001). Principles of Management. New York: Hungry Minds.

Bhatti, O. K., Aslam, U. S., Hassan, A., \& Sulaiman, M. (2016). Employee Motivation: An Islamic Perspective. Humanomics, 32(1), 33 - 47.

BPS-Statistics Indonesia. (2017). Statistical Yearbook of Indonesia 2017. Jakarta: BPS-Statistics Indonesia.

Brinkerhoff, R., \& Apking, A. (2001). High-Impact Learning. Cambridge: MA: Perseus Publishing.

Burns, R. B., \& Burns, R. A. (2008). Business Research Methods and Statistics using SPSS. Singapore: Sage. 
Cheung, H. Y., \& H. Chan, A. W. (2012). Increasing the Competitive Positions of Countries through Employee Training: The Competitiveness Motive Across 33 Countries. International Journal of Manpower, 33 (2), 144 - 158.

Cooper, D. R., \& Schindler, P. S. (2011). Business Research Methods: Eleventh Edition. New York: McGraw Hill.

Creswell, J. W. (2009). Research Design: Qualitative, Quantitative, and Mixed Methods Approaches. Los Angeles: Sage.

Cruz, N. M., Perez, V. M., \& Cantero, C. T. (2009). The Influence of Employee Motivation on Knowledge Transfer. Journal of Knowledge Management, 13(6), 478 - 490.

Danone. (2017). About Danone. Retrieved October 10, 2017, from Danone Community Indonesia: www.dancommunity.com

Dev, M., \& Jyoti, J. (2015). The Impact of Transformational Leadership on Employee Creativity: The Role of Learning Orientation. Journal of Asia Business Studies, 9(1), 78 -98 .

Goldstein, I., \& Ford, K. (2002). Training in Organizations, Need Assessment, Development and Evaluation. Belmont: Wadsworth Thomson Learning.

Immonen, H. A., Koskinen, K. U., \& Porkka, P. L. (2011). The Significance of Formal Training in Project Based Companies. International Journal of Managing Projects in Business, 4(2), 257 - 273.

Ivancevich, J. M., \& Matteson, M. T. (2002). Organizational Behavior and Management: Sixth Edition. New York: McGraw-Hill.

Kyndt, E., Vermeire, E., \& Cabus, S. (2016). Informal Workplace Learning among Nurses. Journal of Workplace Learning, 28(7), 435 - 450.

Liu, Y. S., \& Arendt, S. W. (2016). Development and Validation of a Work Motive Measurement Scale. International Journal of Contemporary Hospitality Management, 28(4), 700 - 716.

Malhotra, N. (2008). Essentials of Marketing: An Applied Orientation (2nd ed.). Australia: Pearson Education.

Neuman, W. L. (2014). Social Research Methods Qualitative and Quantitative Approaches. London: Pearson.

Noe, R. A. (2010). Employee Training and Development. New York: McGraw-Hill.

Noe, R. A., Hollenbeck, J. R., Gerhart, B., \& Wright, P. M. (2015). Human Resource Management: 9th Edition. New York: McGraw-Hill Education.

Ondabu, I. T. (2014). A Theory of Human Motivation: The Tirimba Grouping Theory of Motivation. Economic Research, 1(1), 16 - 21. 
Porter, T. H., Riesenmy, K. D., \& Fields, D. (2016). Work Environment and Employee Motivation to Lead. American Journal of Business, 31(2), 66 - 84.

Radford University. (2013). Statistics Table of Critical Values for R. Retrieved November 21, 2017, from Radford University: Available at: http://www.radford.edu/ jaspelme/statsbook/Chapter\%20files/Table_of_Critical_Values for r. pdf

Royle, M. T., \& Hall, A. T. (2012). The Relationship between McClelland's Theory of Needs, Feeling Individually Accountable, and Informal Accountability for Others. International Journal of Management and Marketing Research, 5(1), 21 - 42.

Sekaran, U., \& Bougie, R. (2013). Research Methods for Business. Chichester: Wiley.

Singh, S. (2015). Effectiveness of Employee Welfare in Maruti Suzuki Varanasi Region. Journal Management Research and Analysis, 2(2), 150 - 161.

Suma, S., \& Lesha, J. (2013). Job Satisfaction and Organizational Commitment: The Case of Shkodra Municipality. European Scientific Journal, 9(17), 41 - 51.

Vanpoucke, E., Lieven, Q., \& Engelshoven, M. V. (2016). The Role of Motivation in Relating Green Supply Chain Management to Performance. Supply Chain Management: An International Journal, $21(6), 732$ - 742.

Yeung, S. M. (2017). Do Research Supervisors Generate Beneficial Learning Outcomes for Learners? The TQM Journal, 29(1), 2 - 18. 